\title{
The comparison of problem solving and working memory of executive functions in postpartum depression women and healthy women
}

\author{
Rogayeh Bahri ${ }^{1}$, Behzad Shalchi' ${ }^{2}$ Hassan Bafandeh Garamaleki ${ }^{3}$ \\ 1-MSc in Cognitive Science,Department of psychology, Faculty of Psychology \& Education Science, Azarbaijan \\ Shahid Madani University, Tabriz, Iran (Corresponding Author). ORCID: 0000-0002-6498-6337 \\ E-mail: Rg.bahry@yahoo.com \\ 2- Associate Professor, Department of Psychology, Faculty of Psychology and Educational Sciences,Azarbaijan \\ Shahid Madani University,Tabriz, Iran. ORCID: 0000-0001-5918-2919 \\ 3-Assistance Professor, Department of Psychology, Faculty of Psychology and Educational Sciences,Azarbaijan \\ Shahid Madani University,Tabriz, Iran. ORCID: 0000-0001-7631-7598
}

Received: 12/05/2019 Accepted: 07/07/2019

\begin{abstract}
Introduction: Postpartum depression is one of the main problems in women's general health, which has a significant effect on the health of mother and child.
\end{abstract}

Aim: The general purpose of this study was to compare the executive functions of problem solving and working memory in women with postpartum depression and women without postpartum depression.

Method: The mothers that referred to Tabriz health centers in 1396, were those who came there 30-40 days after their delivery time. 35 people, who were selected by available sampling method and screened by responding to the postpartum depression questionnaire, were placed in two sample groups; 16 mothers with postpartum depression and 19 healthy mothers matching in terms of age and education. The measuring tools included: Computerized test of the Hanoi Tower for problem-solving and N-Back note test for measuring working memory. Data were analyzed using multivariate analysis of variance (MANOVA).

Results: The results showed that in executive functions of problem solving and working memory both groups did weaker. It can be said that postpartum depression can create different conditions in terms of cognitive-neurological functions in individuals.

Conclusion: Identifying and understanding these factors can lead to a variety of therapies, in addition to helping them better understanding the disorder.

Keywords: Executive function, Problem solving, Working memory, Postpartum depression

How to cite this article : Bahri R, Shalchi B, Bafandeh Garamaleki H. The comparison of problem solving and working memory of executive functions in postpartum depression women and healthy women. Shenakht Journal of Psychology and Psychiatry. 2019; 6 (4): 1-12 .URL: http://shenakht.muk.ac.ir/article-1-594-fa.pdf

Copyright @ 92018 the Author (s). Published by Kurdistan University of Medical Sciences. This is an open access article distributed under the terms of the Creative Commons Attribution-Non Commercial License 4.0 (CCBY-NC), where it is permissible to download, share, remix, transform, and buildup the work provided it is properly cited. The work cannot be used commercially without permission from the journal. 


\title{
مقايسهى كار كر دهاى اجر ائى حل مسئله و حافظهى فعال در زنان مبتلا به افسردكى پس از زايمان و زنان غير افسر دهى سالم
}

\author{
رقيه بحرى'، بهزاد شالجىى'، حسن بافنده قر املكى ' \\ ا.كارشناسى ارشد روانشناسى شناختى، دانشكده علوم تربيتى و روانشناسى، دانشگاه شهيد مدنى آذربايجان، تبريز، ايران (مولف مسئول). \\ Rg.bahry@yahoo.com : ايميل \\ ז.دانشيار، گروه روانشناسى، دانشكده علوم تربيتى و روانشناسى، دانشگاه شهيد مدنى آذربايجان، تبريز، ايران.

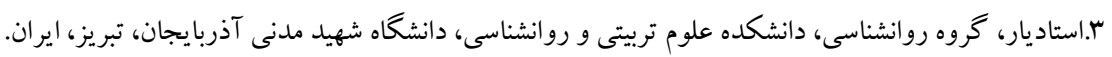

مقدمه: افسردگى بس از زايمان، يكى از مشكلات اساسى در حوزهُ سلامت عمومى زنان است كه تأثير برجستهاى روى سلامت مادر و كود كك دارد.

هدف: هدف كلى بثزوهش، مقايسٔ كار كردهاى اجرايى حل مسئله و حافظهى فعال در زنان مبتلا به افسردگى بس از زايمان و زنان غير افسردمى سالم بود.

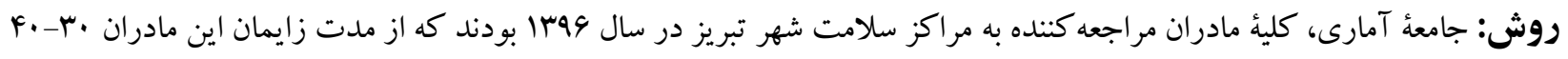

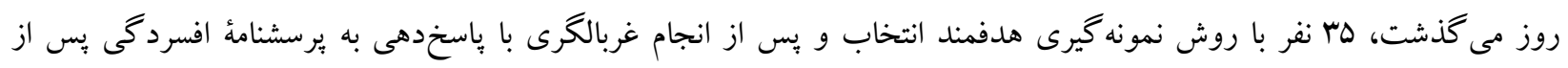

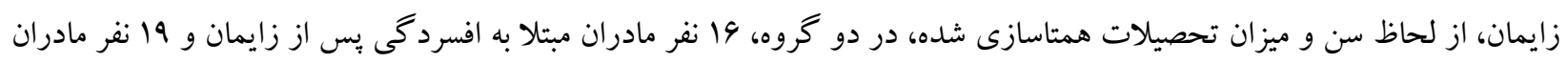

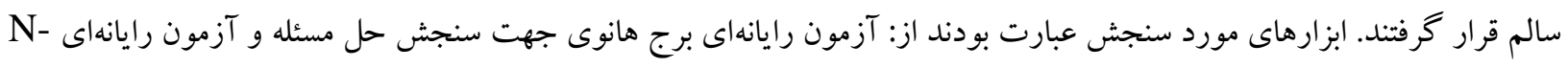

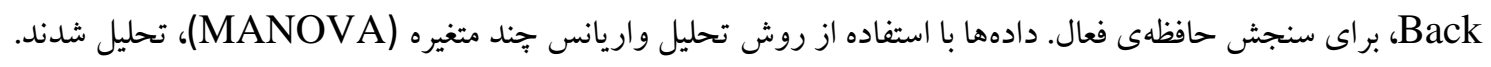
يافتها: نتايج نشان داد كه در كاركردهاى اجرائى حل مسئله و حافظه فعال، هر دو گروه ضعيفتر عمل نمودند. مىتوان كفت

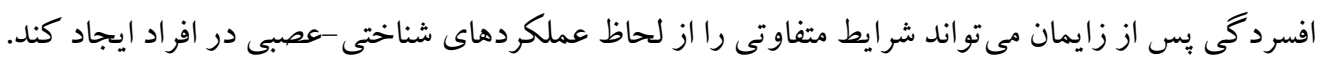
نتيجه كيرى: شناسايى و فهم اين عوامل مى تواند علاوه بر كمكك به دركك بهتر اين اختلال، به ارائه راهكارهاى مختلف درمانى منجر

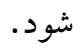
كليد وازهها: كار كردهاى اجرائى، حل مسئله، حافظهى فعال، افسردگى يس از زايمان 
عليرغم تلاشهاى رو به افزايش براى شناسايى و

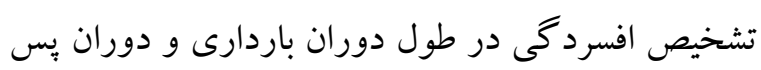
از زايمان، نرخ شيوع اين اختلال هنوز بالاست. ميزان شيوع اين اختلال در طول س ماهه نخست بس از زايمان، تقريباً سا درصد است. در حالى كه بسيارى از زنان در طول جند ماه يس از ابتلاء به اين اختلال، بهبود مى يابند،

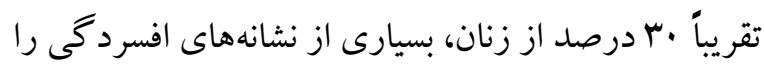
در طول يكك سال بِ از زايمان، هنوز تجربه مى كنند و

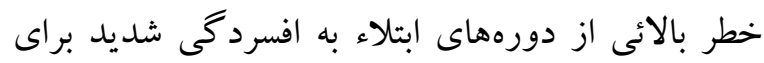

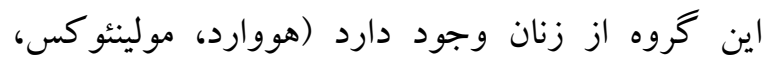

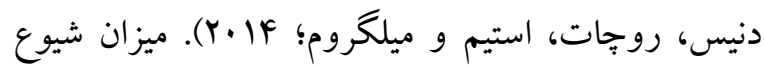

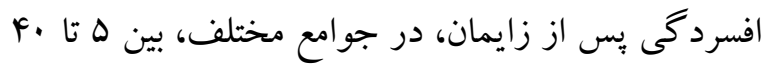
درصد است، در ايران، بر اساس مطالعات مختلف، به

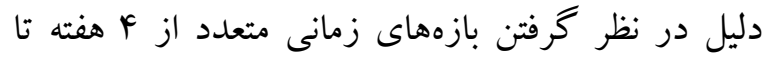
يكك سال بس از زايمان، نتايج متفاوتى (V تا سم درصد)، گزارش گُديده است. ميزان شيوع افسردگى يس از

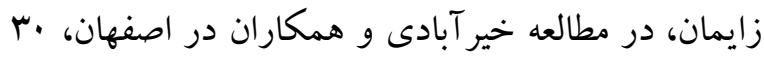
r. درصد، در مطالعه دولتيان و همكاران در تهران، درصد، گزارش شده است (ويسانى و سايه ميرى؛ Y (Y. ). متخصصين حرفه سلامت در حوزه تخصصى زنان و مامائى و همجنين، عصب روانشناسان بالينى، از نقايص شناختى خود گزارشى كه توسط بسيارى از زنان در دوران بس از زايمان، تجربه مى شود، به خوبى آكاهى دارند، به نظر مى رسد، نقايص در كار كردهاى شناختى -

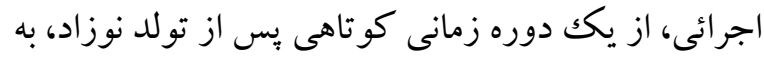
وجود مى آيند كه هم مادر و هم نوزاد را تحت تأثير قرار مىدهند (مسينيس، ولاهو، تسايانوس، تسايانوس،

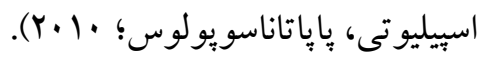

\section{مقلمهه} افسردگى پس از زايمان'، دورهاى از افسردگى است كه F-9 هفته يس از تولد نوزاد روى مىدهد و با علائم و نشانهايى از احساس غم و اندوه (تقريباً (هر روز)) فقدان لذت در نقش مادرى، بى علاقه بودن و احساسات منفى نسبت به نوزادى كه تازه متولد شده، احساس كناه در مورد توانائى والد مؤثر بودن، توجه و تمركز ضعيف، بىخوابى و بىاشتهائى مشخص مى مردد (داناسب و و

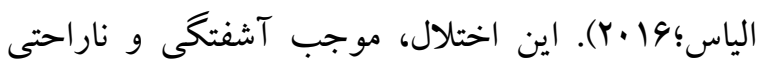
مادر شده و توانائى مادر براى مراقبت از خود و نوزاد و نيز رسيدگى به كارهاى روزمره و عادى زندگى را تحت تأثير قرار مى نهد. اختلال افسردگى بـ بس از زايمان، روى مادر، نوزاد و خانواده و همجنين بر روابط مادر-نوزاد تأثيرات منفى جدى مى گذارد (اباينه، بيليسوما، تيبا، تادس برد

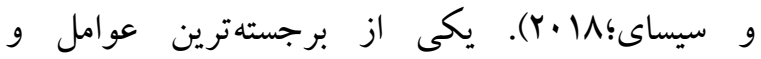
فاكتورهاى خطر ابتلاء به افسردگى بس از زايمان، ابتلاء

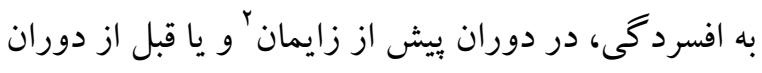
باردارى است. متأسفانه، راهنماى تشخيصى و آمارى

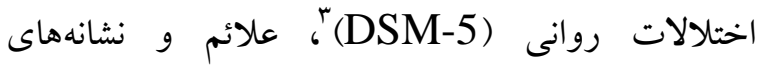
افسردگى را كه مى تواند بِ از جهار هفته بعد از زايمان نيز به وجود آيد، در نظر نمى گيرد. علاوه بر اين، بين شروع در دوران باردارى و شروع در دوران يس از زايمان در ابتلاء به اختلالات افسردگى، تمايزى قائل نمىشود، به عبارتى ديخر، در اين راهنماى تشخيصى، تنها به دورههايى با عنوان دورههاى افسردگى اشاره كرديده است (بروملت و كاليا؛ 19 (Y).

\footnotetext{
${ }^{1}$. postpartum depression

2. prenatal

3. diagnostic and Statistical Manual of Mental Disorders-Fifth Edition
} 
دارند. داناسب و الياس، در مطالعه يثوهشى خود به اين نتيجه دست يافتند كه بين توانائى حل مسئله و افسردگى

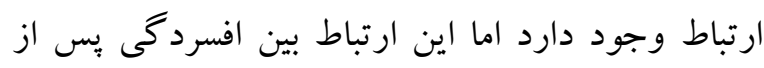

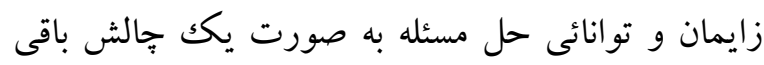
مانده است. اين محققين در راستاى مطالعه ئزوهشى خود

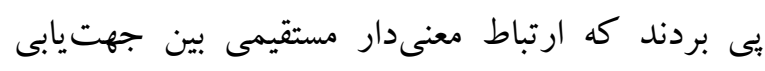
مثبت مسئله و افسردگى بس از زايمان، وجود دارد اما بين جهت يابى منفى مسئله و افسردگى پس از زايمان رابطه

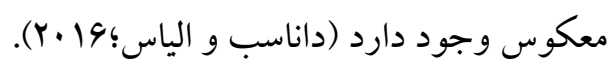
به دليل اهميت وافر اين موضوع، سلامت جسمانىروانى مادر و متعاقباً تأثير آن بر سلامت جسمانى -روانى

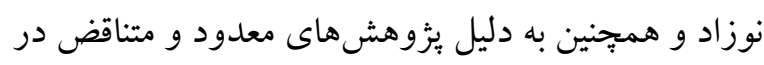

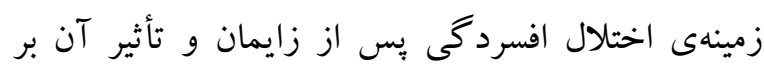

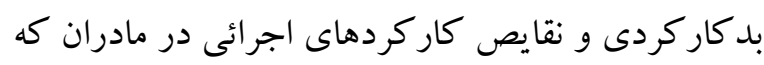

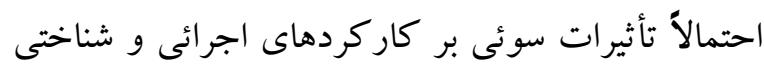
نوزاد و كودكك خواهد كذاشت و از آنجائى كه، كاركردهاى اجرائى همجيون توانائى حل مسئله، براى

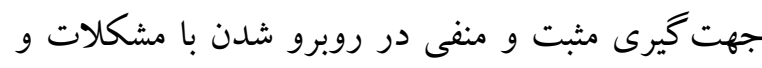
حافظه فعال در مادران تازه زايمان كرده به خوبى مطالعه نخرديده است، به دليل وجود اين خلأ مهم در بثزوهشها، مسئلهى يثزوهشى اين است كه آيا بين كاركردهاى اجرايى حل مسئله و حافظهى فعال در زنان مبتلا به افسردگى بس از زايمان و زنان غير افسرده پس از زايمان،

تفاوتى وجود دارد يا نه؟

روش مطالعه مطالعه حاضر به لحاظ شيوه گردآورى دادهها، از نوع يثزوهشهاى على -مقايسهاى يسرويدادى است و از لحاظ هدف در رديف تحقيقات بنيادى قرار مى گيرد. اين مطالعه مورد تأييد كميته اخلاقى دانشگاه علوم يزشكى دردي
كاركردهاى اجرائى، به عنوان اصطلاحى براى توصيف

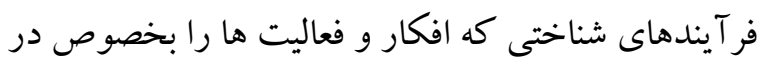
يكك موقعيت غيرعادى تنظيم مى نمايند، به كار گر فته مى شوند. نمونه هايى از جنين فر آيندهايى كه در اصطلاحاتى از روانشناسى شناختى تعريف شده اند، عبارتاند از: حل

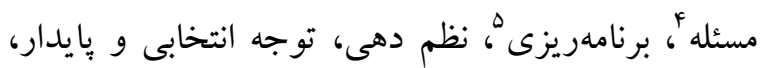

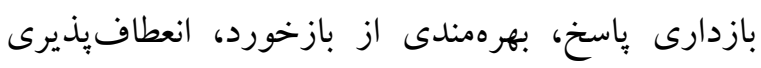
شناختى و توانائى براى يرداختن به جيزهاى نو و بـ بديع

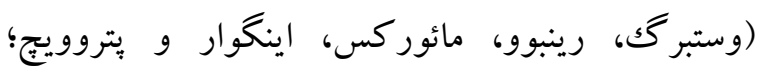

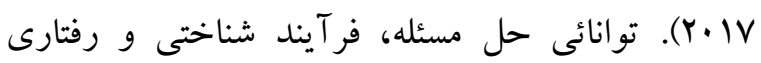
مؤثرى است كه فرد تلاش مى كند تا راهحل مؤثرى براى مسائل كشف كند. اين فر آيند، جهت يابى مسئله و مهارت حل مسئله را شامل مى گردد كه مؤلفههاى مستقل از هم

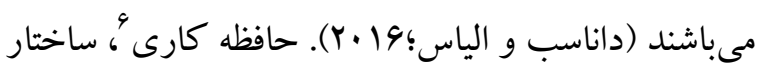
نظرى ييجيدهاى است، در حالى كه مفهومسازى حافظه كارى در ميان نظريه بردازان، به شدت متفاوت است، بيشتر محققين بر اين باورند كه حافظه كارى يكك جنبه

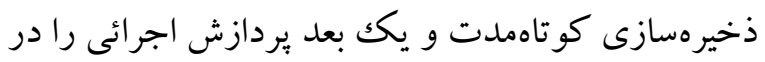
برمى گيرد. حافظه كارى، يكك سيستم با ظرفيت محدود است، از اين رو در اين سيستم، يكك مقدار نسبى از اطلاعات در طول يكك دوره خيلى محدود زمانى ذخيره

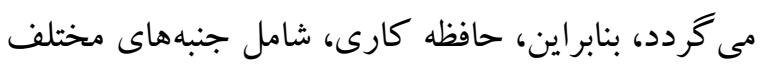
يردازش اطلاعات است و به عنوان يكك ساختار جند منظوره با ذخيرهسازى تعاملى و بردازش اجرائى در نظر

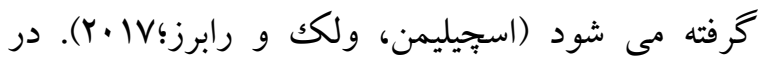
مطالعات صورت گرفته در اين زمينه مشخص گرديده است كه افراد مبتلا به افسردگى پِ از زايمان، در برخى از توانائى هاى مربوط به كاركردهاى اجرائى نقايصى

\footnotetext{
4 . problem solving

5. planing

${ }^{6}$. working memory
} 
سنى ·r-r سالكى، اعلام رضايت داوطلبين بر اساس فرمهاى رضايت آكاهانه براى مشاركت در يُوهش، تشخيص ابتلا به افسردگى يس از زايمان توسط رصائ

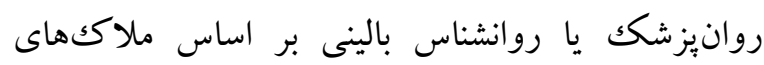
تشخيصى DSM-5 و بر اساس باسخ گويى به سؤالات

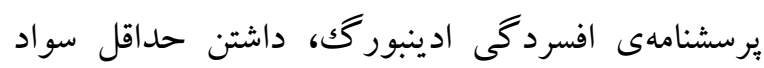
خو اندن و نوشتن (حداقل مقطع راهنمايى)، فقدان اختلال روانى بارز ديخر بر اساس DSM-5، فقدان اختلالات نورولوزيكك مانند صرع، آسيب مغزى، راست دست بـ بودن، ميانكين ضريب هوشى بين ·9-·11، آشنايى با روش كار رايانه. ملاككهاى خروج عبارت بودند از: بروز افكار جدى خود كشى و احتمال خطر خود كشى كه نياز به مداخله فوريتى را ايجاب مىنمود، استفاده از مواد اعتيادآور، وجود سكته مغزى، تومور، بيمارىهاى قلبى، بيمارى هاى كبدى، منتزيت، آرتروز، وجود مشكلات ديدارى، شنيدارى، حركتى و ارتباطى. در كام اول بِ از لـ توضيحات در مورد اين طرح يثوهشى رضايت افراد كروه هاى آزمايشى و كنترل با استفاده از رضايتنامه كتبى اخذ گرديد. مادران گروه هاى نمونه بر اساس

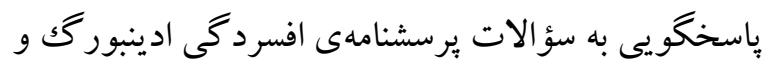
تشخيص ابتلا به افسردگى پيس از زايمان توسط DSM- روانشناس بالينى بر اساس ملاككهاى تشخيصى

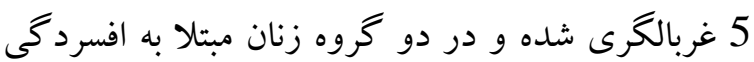
״س از زايمان و گرووه زنان غير افسرده سالم، قرار گرفتند و يس از اطمينان از آشنايى مادران با رايانه و برخوردارى توانائى استفاده از رايانه و نيز آشنايى با دستورالعمل انجام آزمونها كه توسط خود بزوهشخر ارائه گرديد؛ آزمونهاى رايانهاى عصب-روانشناختى شامل آزمونهاى
تبريز قرار گرفت و از مادران مورد مطالعه رضايتنامهكتبى آكاهانه اخذ گرديد. در اين يزوهش، جرامعه آمارى، كليه زنان در بازه سنى ·r تا ها ساله بودند كه در سال وهץ|، دوران باردارى و زايمان خود را در فاصله زمانى ·r تا • F روز بعد از زايمان، بدون هيج مشكلى در ارتباط با باردارى و زايمان سيرى نموده و نوزاد سالم و زنده به دنيا آورده بودند و جهت بهرهمندى از هر گونه خدمات بهداشتى-درمانى، به يكى از مراكز سلامت منتخب دانشگاه علوم بزشكى شهر تبريز، مراجعه كرده بودند. از بين جامعه آمارى فوقالذكر، •ها نفر از زنان مراجعه كننده به عنوان نمونهى آمارى انتخاب كرديدند. با ادامه روند آزمونگيرى از شركت كنندگان در طرح تحقيقى، فراوانى شركت كنند كان به علت عدم مشار كت و نيز به دليل شرايط خاص مادران در دوران يس از زايمان و نخرانىهاى مادرانه در مورد مراقبت از نوزادان خود، كاهشيافته و تعداد شركت كنند گان به ها نفر رسيد. به علت گسترده بودن توزيع جغرافيايى جامعه آمارى، نمونه آمارى با روش نمونه كيرى خوشهاى جند مرحلهاى، انتخاب گرديد كه NV مركز سلامت شهر تبريز بر اساس درجهبندى و موقعيت جغرافيايى به f منطقه تقسيمشده و از هر منطقه به طريق نمونه كيرى ناحيهاى يا خوشهاى به تعداد ·r مركز سلامت جهت انجام يثوهش و نمونه گيرى انتخاب شدند، سبس بر اساس ويثز گیىها و ملاككهاى ورود و خروج، آزمودنىهاى تحقيق با روش نمونه كيرى هدفمند انتخاب گرديده و به منظور كنترل

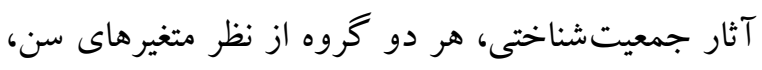
ميزان تحصيلات و هوش همتاسازى شدند و از لحاظ توانائى حل مسئله و حافظه كارى مورد مقايسه قرار كرفتند. ملاكك هاى ورود عبارت بودند از: محدودهى 
از زايمان در نظر گرفته مىشود. اعتبار علمى اين برسشنامه، به روش دو نيمه كردن MN/ و و به روش

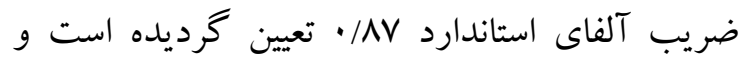
اعتبار علمى آن نيز توسط كاكس و همكاران در سال 19AVV

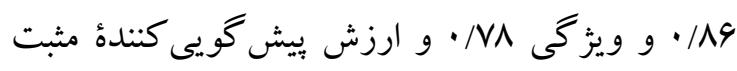

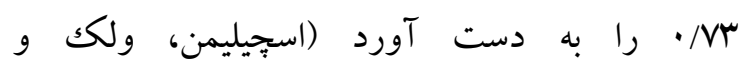

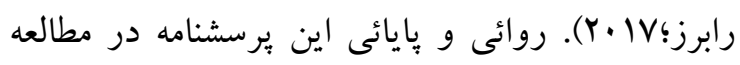

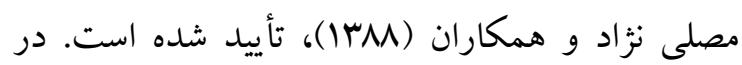

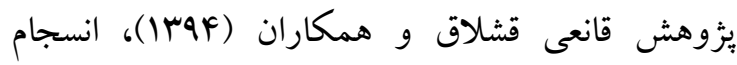

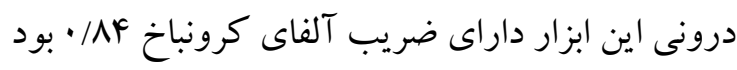

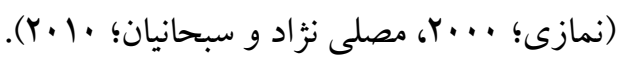
آزمون رايانهاى برج هانوى: اين آزمون اولين بار توسط شاليس در سال ra191 ساخته شد. معماى برج هانوى تر كيبى است از ب ميله كه تعدادى ديسك نيز بر روى اين ميله ها قرار مى كيرد و از يايين به بالا هر

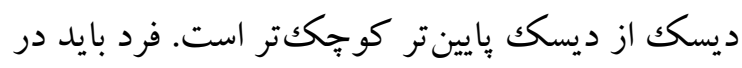

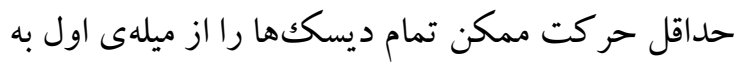
ميلهى آخر (از ميله ا به ץ) حركت دهد به كونهاى كه ترتيب اوليهى ديسك ها بر روى ميله اول بر ميلهى هدف نيز حفظ شود. فرد بايد در هر زمان يكك ديسك

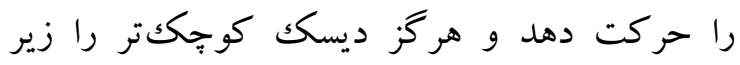

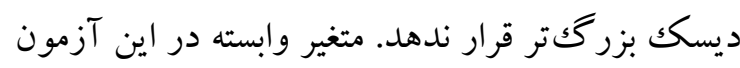
عبارت است از نسبت دستيابى به حداقل حر كات كه از تفريق كل حركات انجامشدهى آزمودنى از حداقل حر كات لازم براى حل مسئله به دست مى آيد. رقمى كه به اين شيوه به دست مى آيد، نشاندهندهى خطاهاى آزمودنى در انجام تكليف است. آناستازى و اوربينا (199V) به نقل از تانستال،1999) با تبديل كل راه حل
رايانهاى برج هانوى و N-Back، توسط مادران تكميل كرديدند.

ابز ار در بزوهش حاضر ابزار كردآورى دادهها شامل F قسمت

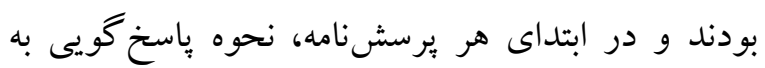

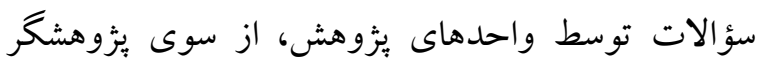
توضيح داده شد. براى جلو گيرى از دخالت اثر توالى، ترتيب آزمونها به طور تصادفى تغيير داده مىشد. آزمونشوند گان مى توانستند در اجراى بين دو آزمون استراحت نمايند. ابزارها عبارت بودند ازئ

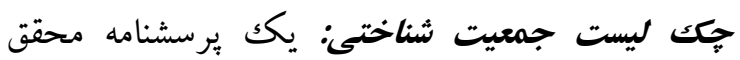
ساخته است كه شامل ·F سؤ ال در مورد مشخصات فردى واحدهاى مورد يزوهش همجون: سن، ميزان تحصيلات مادر، شغل، تعداد فرزندان، ترتيب تولد، ميزان تحصيلات بدر، شغل همسر، وضعيت مسكن، سلامت جسمانى و روانى، رابطه مادر-فرزند، آشنايى تهري با رايانه و ميزان استفاده از رايانه، است. يرسشنامه افسردكى يس از زايمان ادينبوركى': اين "يرسشنامه، اولين بار توسط كاكس و همكاران، در سال 191VV عبارت داراى ع بِاسخ است، تشكيل شده است. اين يرسشنامه نيازمند حدود ه دقيقه زمان جهت تكميل

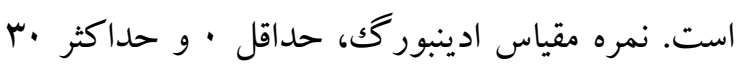

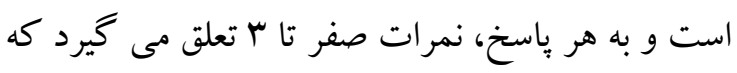

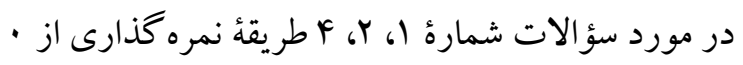

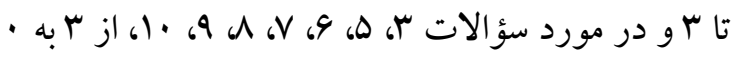
است و با جمع نمرات، نمره كلى فرد محاسبه مى گردد.

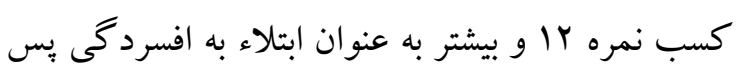

${ }^{7}$. Edinburgh Postnatal Depression Scale 
عنوان شاخص سنجش عملكرد حافظه كارى بسيار قابل قبول است. در مطالعات گوناكون، كاربردهاى مختلفى در حيطه حافظه كارى براى آزمون n تعداد به عقب، به

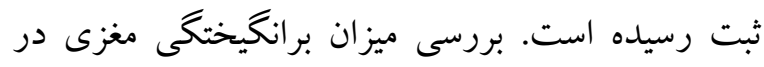
هنگام فعاليت حافظه كارى، بررسى تفاوت هاى فردى در حافظه كارى يا سنجش عملكرد حافظه كارى در گروه

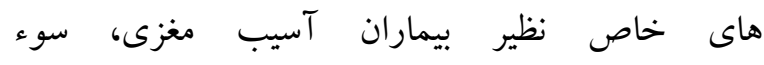

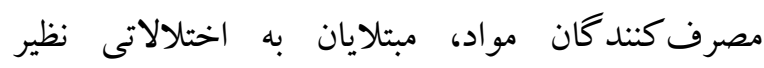

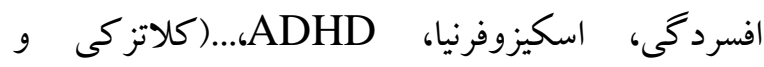

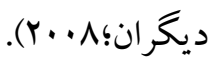

\section{يافته ها}

براى تجزيه و تحليل دادههاى تحقيق، از روشهاى آمار توصيفى و آمار استنباطى استفاده شد. يس از جمع آورى

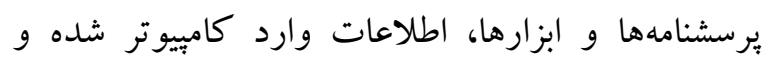
سبس با استفاده از نرمافزار كامييوترى سوكSPS، نتيجه اطلاعات استخراج گرديده و تجزيهوتحليل آمارى دادهها صورت گرفت و سطح معنىدارى ينج صدم براى آزمونهاى آمارى در نظر كرفته شد.

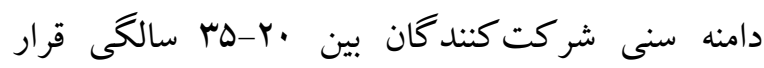
داشت. ميانگين سنى آزمودنى هاى افسرده بس از زايمان،

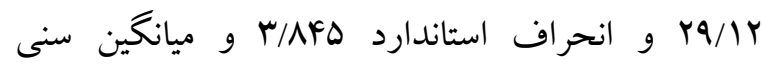
آزمودنىهاى غير افسرده، Y و انحراف استاندارد به/A9 است. از لحاظ وضعيت تحصيلى در گرووه مادران مبتلا به افسردگى يس از زايمان، M/A درصد زير دييلم، WV/ه درصد دييلم، 1/N/A درصد فوق دييلم، 1N/1 درصد ليسانس، س/9 درصد دكترى، در گرووه مادران غير افسرده

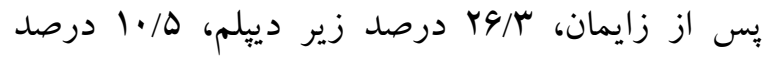
دييلم، 1ه/A درصد فوق دييلم، آس درصد ليسانس، 1ه/1 درصد فوق ليسانس گزارش گرديده است.
اين آزمون به يكك سرى سؤالات شفاهى در مورد حركات ديسك ها، هماهنكى درونى باسخ به اين سؤالات را مورد ارزيابى قرار داده و آلفاى كرونباخ معادل N9/ • را براى اين آزمون را محاسبه كردند. زيلمر

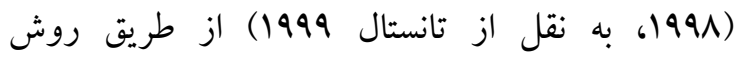

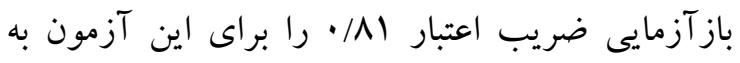
دست آورد (قانعى قشلاق، محمودى و باقى؛ ها·Y). براى نمره گذارى آزمون، تعداد حر كاتى كه آزمودنى

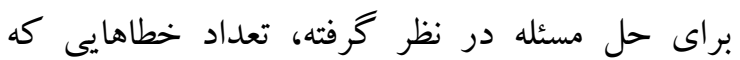
آزمودنى در حين آزمون مرتكب شده و مدت زمانى

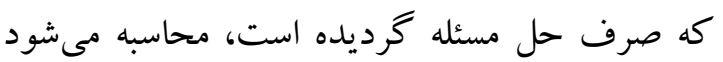

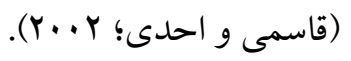

آزمون رايانهاى N تعداد به عقب؛؛ اين آزمون براى نخستين بار توسط كرجنر در سال 1901 معرفى شد. روند كلى تكليف بر اين قرار است كه دنبالهاى از محركهيا (عموماً ديدارى) به صورت كام به كام، به آزمودنى ارائه مى شود، آزمودنى بايد بررسى كند كه آيا محرك ارك ارائه شده فعلى، با محر كى n گام قبل از آن، همخوانى دارد

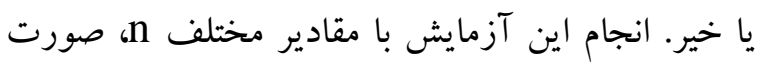

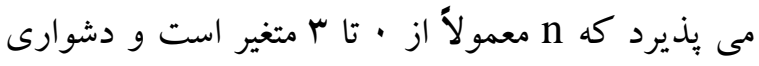
آزمون را با افزايش ميزان n تعيين مى كند. بدين ترتيب

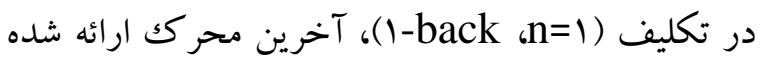
با محركى قبلى مقايسه مى شود و در تكليف (س=r) Mback مقايسه خواهد شد. از آنجا كه اين تكليف هم نكهدارى

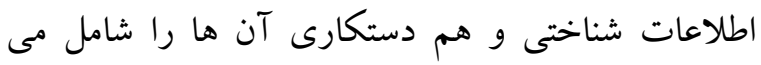
شود، براى سنجش عملكرد حافظه، بسيار مناسب شناخته

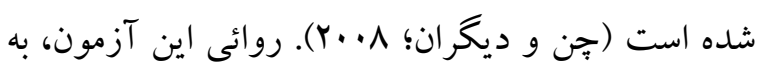

\footnotetext{
${ }^{8}$. N-back Task
} 


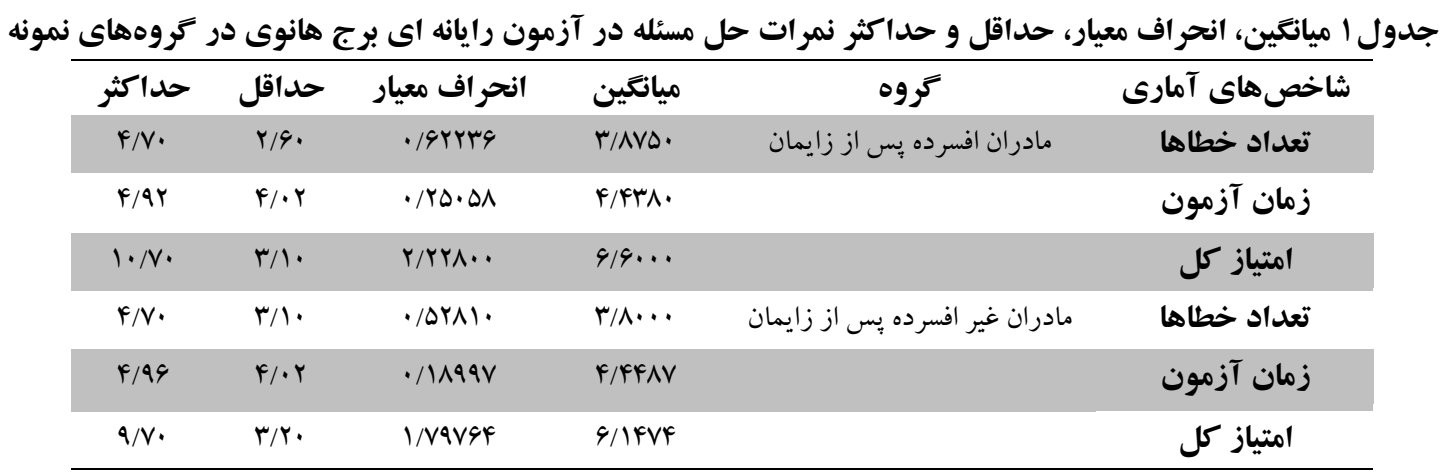

در جداول او Y آمار توصيفى متغيرهاى بزٔوهشى شامل، نشده) كه به تفكيك هر دو كروه مادران مبتلا به

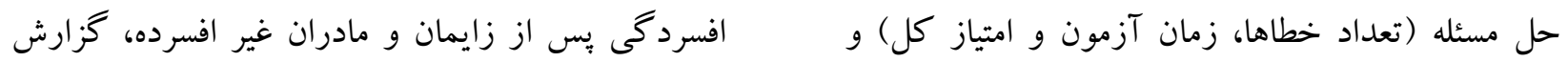

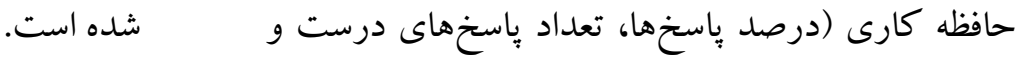
نادرست، ميانخين زمان واكنش و تعداد بِاسخهاى داده

\begin{tabular}{|c|c|c|c|c|c|}
\hline \multicolumn{2}{|c|}{ مادران سالم } & \multicolumn{2}{|c|}{ 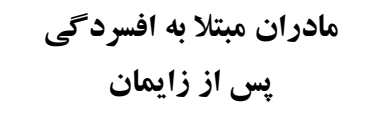 } & \multirow[t]{2}{*}{ شاخص هاى آمارى } & \multirow[t]{2}{*}{ شماره } \\
\hline انحر اف معيار & ميانكين & انحر اف معيار & ميانغين & & \\
\hline YY/YVD & $9 N / Y 1$ & $r \cdot / f r q$ & $q \mu / .$. & درصد ياسخها & \\
\hline YG/VID & $\Lambda I / \Lambda F$ & TF/OYV & $V Q / 9 T$ & تعداد ياسخهاى صحيح & \\
\hline V/aYV & $V / 9 \Delta$ & V/Arı & $9 / 99$ & تعداد ياسخهاى نادرست & سطح 1 \\
\hline IVG/MFV & $9 M / V q$ & $194 / V 99$ & VYI/rA & ميانگين زمان واكنش & \\
\hline rQ/9Ar & $r \cdot / r l$ & YV/AGI & $\mathrm{rV} / 99$ & تعداد پِاسخهاى داده نشده & \\
\hline IV/THA & $\Delta \cdot / 9 \Delta$ & $r \cdot / 49 \Lambda$ & $\Delta r / \cdots$ & درصد ياسخ ها & \\
\hline$r \cdot / \Lambda \mu_{\Lambda}$ & $91 / 11$ & YI/rMQ & $q \pi / 0$. & تعداد ياسخهاى صحيح & \\
\hline $14 / 909$ & rM/lq & $19 / 0 V r$ & $r F / T \Lambda$ & تعداد باسخهاى نادرست & سطح r \\
\hline $\mid \wedge 9 / \mu \cdot F$ & $\Lambda \cdots / r V$ & $r 1 \cdot / 110$ & $V G V / I r$ & ميانگين زمان واكنش & \\
\hline$r \cdot / v \wedge$. & $r \Delta / v e$ & $M 1 / 911$ & $r \mathrm{r} / \mathrm{ll}$ & تعداد ياسخهاى داده نشده & \\
\hline $19 / 9 \cdot F$ & $F \Delta / Q F$ & $\mathrm{IV} / \cdot 9 \mathrm{Y}$ & $F q / F V$ & درصد ياسخها & \\
\hline 19/DrV & $\Delta G / F F$ & $r \cdot / 49 \Lambda$ & $\Delta \Delta / V r$ & تعداد باسخهاى صحيح & \\
\hline $19 / \cdot 91$ & $M I / I V$ & $r \cdot 1991$ & $r F / I r$ & تعداد ياسخهاى نادرست & سطح r \\
\hline $191 / 9 \cdot f$ & VYF/AQ & $r .9 / \mathrm{VWV}$ & $V \cdot N / I r$ & ميانگين زمان واكنش & \\
\hline$r / \wedge 9 \Delta$ & $r r / r q$ & rV/ADQ & $r \cdot / \mu$ & تعداد ياسخهاى داده نشده & \\
\hline
\end{tabular}

به منظور مقايسه دو گروه در متغيرهاى كاركردهاى متغيرى(MANOVA) استفاده شد. بررسىهاى لازم اجر ائى حل مسئله و حافظه فعال، از تحليل واريانس جند جهت اطمينان از عدم تخطى از مفروضه هاى انجام تحليل 
سطح معنادارى نشاندهنده عدم تخطى از مفروضهى فوق است؛ بنابراين نتايج مربوط به تحليل واريانس جند متغيره در جدول بمطرح مى گردند.
واريانس جند متغيره انجام يافت. معنادار نبودن آزمون لون براى هيج يكك از متغيرهاى آزمون، برقرارى مفروضه تئه همكنى واريانس ها در مراحل تحت بررسى را نشان داد. همجنين براى مفروضهى برابرى ماتريس واريانس ها،

جدول r نتايج آزمون تحليل واريانس جند متغيره در شاخص آمارى حل مسئله و n تعداد به عقب

\begin{tabular}{|c|c|c|c|c|c|c|c|}
\hline سطح & مجذور اتا & درجه آزادى & تحليل واريانس & مقدار & متغير وابسته & شاخص & منبع \\
\hline . /qr. &.$/ .1 f$ & m &.$/ 1 F 9$ & $\cdot / 919$ & حل مسئله & لامبداى ويلكز & كروه \\
\hline.$/ \% \Lambda$ & - /QYV & $r$. & • rIV & . $/ 9 V Y$ & n-back & & \\
\hline
\end{tabular}

نمى گردد و يكك راه حل را حدس مىزند، آن را امتحان مى كند و سراغ راهحل ديخر مىرود (دزوريلا و كلدفريد؛ (19VI). در فر آيند حل مسئله جندين عامل نقش برجسته اى را ايفا مى كنند. يكى از اين عوامل، نياز به شناخت عنوان شده است. كاسييو و يتى (19AY)، نياز به شناخت را به تمايل فرد براى درگير شدن و لذت بردن از فعاليت شناختى كه نيازمند تلاش است، تعريف نمودهاند. افرادى كه نياز به شناخت بالائى دارند اطلاعات در دسترس را به خوبى تحليل كرده و معانى آن را بهتر

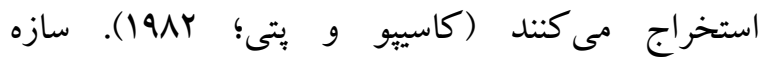
روانشناختى ديخر كه در فرآيند حل مسئله مطرح است، تكانش گرى است. افراد تكانش گر بدون در نظر گرفتن اثرات فعاليت خود دست به اقدام عاجل مىزنند، اين

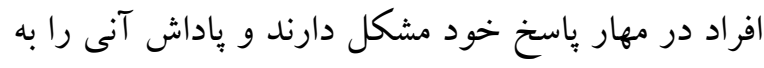
ييامد تأخيرى ترجيح مىدهند. افراد تكانش گر به دليل سبك يردازش اطلاعات سريع در بازدارى ياسخ با مشكل فرئ

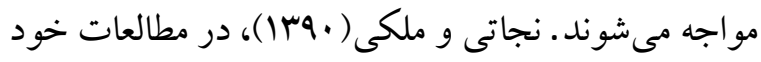
به اين نتيجه دست يافتند كه تكانش گرى و تأمل گرايى

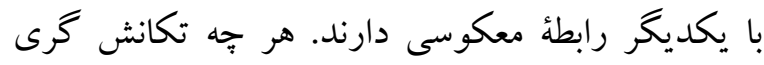
بيشتر باشد تعداد حر كات آزمودنى در فر آيند حل مسئله
همان گونه كه در جدول ب قابل مشاهده است، دو گروه در متغيرهاى حل مسئله و حافظه فعال تفاوت معنادارى با يكديگر ندارند.

اين مطالعه با هدف مقايسه دو گرووه زنان مبتلا به افسردگى يس از زايمان و زنان غير افسرده سالم به لحاظ كاركردهاى اجرائى حل مسئله و حافظه فعال انجام كرديد. يافتهاى اين مطالعه نشان داد كه بين دو گروه از نظر كاركرد اجرائى حل مسئله تفاوت معنادارى وجود ندارد؛ دزوريلا و كلدفريد ( (19VI)، در مورد توانائى حل مسئله ينج مرحله را شناسايى نمودهاند كه عبارتاند از: شناسايى موقعيت مسئله، تعريف و صورت بندى مسئله، به وجود آوردن راه حل هاى نو، تصميم گيرى و اثبات (سولسو؛ 19V9). يافتن راهحل مسئله نيازمند دامنهاى از مهارتهاى شناختى مشتمل بر تفسير اطلاعات، برنامهريزى، حافظه روششناسانه، كنترل نتايج و تلاش براى تغيير نتايج است. از طرفى ديخر حل مسئله به نحو خلاقانه مستلزم به كار گيرى تعدادى از راهبردهاى اكتشافى است. در راهبردهاى اكتشافى، فرد درگير تفسير و تحليل نتايج 
ندارند. از علل اساسى تبين اين يافته به تفاوت در ابزارهاى به كار گرفته شده در اين يزوهش و ساير يخزوهشها مى توان اشاره كرد خرا كه ئزوهشهاى انجام يافته بيشتر آزمونهايى را به كار كرفتهاند كه حهان حافظه كلامى و حافظه شنيدارى را مىسنجند. براى هماهنكى لئى در ابزارهاى مورد استفاده براى سنجش عملكرد حافظهى

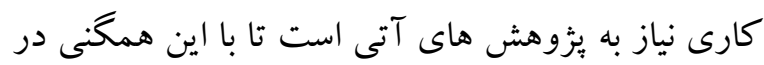

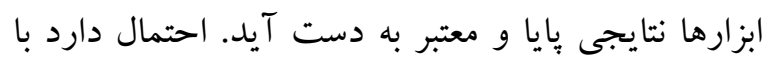

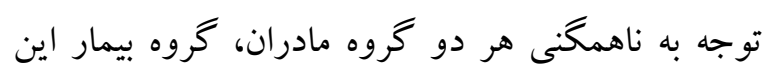
مطالعه دربر گيرنده آن بيمارانى باشد كه نقايص نورولوزيكك جدى ندارند، اگرجه در حال حاضر هيج شاهدى بر اين ادعا وجود ندارد. اين يافته همسو با يافته

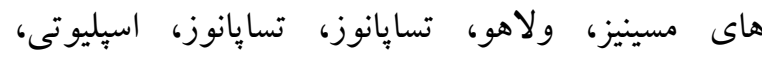

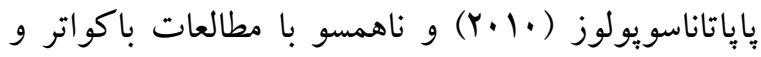

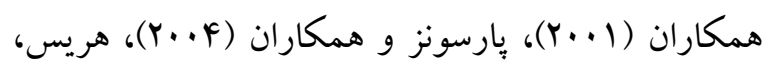
درى، ليز، ويلسون (1999) مىباشد (آنتونى دى،

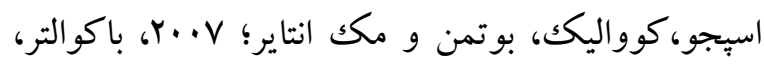

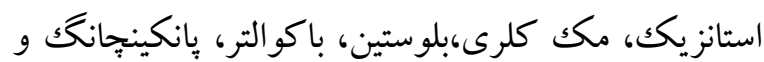

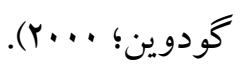

\section{نتيجه كيرى}

در مجموع نتايج بهدست آمده از اين مطالعه نشان داد كه بين دو گروه از مادران افسرده پيس از زايمان و مادران غير افسرده يس از زايمان به لحاظ كاركردهاى اجرائى حل مسئله و حافظه فعال تفاوت معنىدارى وجود ندارد. مطالعات اندكى در ارتباط با همبستهاى عصبى اختلالات عاطفى، زمانى كه اين اختلالات در مادران رخ مىدهند، صورت گرفته است، اما اين اختلالات در طول دوره يس از زايمان، در مقايسه با زمانهاى ديخرى كه در طول زندگى يكك زن رخ مىدهند، داراى يروفايل هاى
بيشتر است. بر اساس مطالعات مسر نيز افراد تكانش كر در رويارويى با مسائلى كه داراى بِاسخ قطعى نيستند بدون دقت عمل مى كنند، در حالى كه تأمل گراها راهحل هاى مختلف را بررسى كرده و يس از دقت و تأمل فراوان ياسخ خود را ارائه مىدهند. بر اساس اين يافتههاى بثزوهشى مىتوان جنين نتيجه گرفت كه مادران به دليل شرايط فيزيكى خود در دوران بس از زايمان و نيز به دليل شرايط محيطى موجود و نگگرانى از نوزاد خود، در آزمون رايانهاى برج هانوى به صورت تكانشى عمل نموده و از توانائى نياز به شناخت يائينى برخوردار بودند بنابراين هم تعداد خطاها بالا رفته و هم تعداد حر كاتى كه براى حل مسئله انجام دادهاند بيشتر شده است و اين حالت در هر دو گروه شبيه هم است، بنابراين مادران هر دو گروه مطالعه، به دليل تكانشى عمل نمودن و انعطاف يذيرى روانشناختى پائين بر اساس توانائى نياز به شناخت پائين، اطلاعات در دسترس را بررسى نكردهاند و نتوانستند از راهبردهاى مؤثر حل مسئله در آزمون برج هانوى استفاده كنند و نتايج آزمون را تحت تأثير قرار دادند. اين نتايج ناهمسو با نتايج مطالعات دناسبه و الياس (19 (Y)، اليوت،

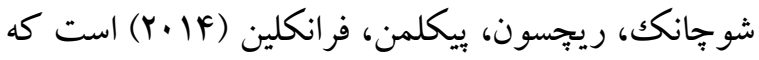
علت اصلى اين نا همسوئى به دليل تفاوت ابزارى است كه اين دو مطالعه با مطالعه ما دارد. در اين دو مطالعه از يرسشنامه جهت يابى مثبت و منفى در فر آيند حل مسئله در دوران بِ از زايمان استفاده گرديده، در حالى كه ما در مطالعه خود آزمون رايانهاى برج هانوى را كه عملكرد ناحيه DLPFC مغز را مىسنجد استفاده كردهايم. در يافته دوم، نيز مشاهده مىشود كه مادران مبتلا به افسردگى يس از زايمان، از لحاظ كار كرد اجرائى حافظه دئه كارى با مادران غير افسرده سالم، تفاوت معنىدارى 
Abayneh S, Bilisuma T, Tiba A, Tadesse M, \& Sisay S. (2018). Prevalence of Postpartum Depression and Associated Factors among Postnatal Women Attending At Hiwot Fana Specialized University Hospital, Harar, East Ethiopia, 2015/2016. Open Acc J Repro \& Sexual Disord, 1(1)-2018. OAJRSD. MS.ID.000102.

Aeschlimann EA, Voelke AE, \& Roebers CM. (2017). Short-Term Storage and Executive Working Memory Processing Predict Fluid Intelligence in Primary School Children. Journal of Intelligence, $\quad 5, \quad 17$; doi:10.3390/jintelligence5020017.

AnthonyDay E, Espejo J, Kowollik V, Boatman PR \& McEntire LE. (2007). Modeling the links between need for cognition and the acquisition of a complex skill. Personality and Individual Differences,42(2), 201-212.

Brummelte S, \& Galea LAM. (2016). Postpartum depression: Etiology, treatment and consequences for maternal care. Hormones and Behavior, 77. 153-166.

Buckwalter JG, Stanczyk FZ, McCleary CA, Bluestein BW, Buckwalter DK, Rankin KP, Chang L, \& Goodwin TM. (2000).Pregnancy, the postpartum, and steroid hormones: effects on cognition and mood. Psychoneuroendocrinology, Volume 24, Issue 1, Pages 69-84.

Cacioppo JT, \& Petty RE.(1982). The need for cognition. Soc Psychol Personal; 42(3):116131.

Cox JL, Holden JM, \& Sagovsky R.(1987). Detection of postnatal depression: development of the 10-item Edinburgh Postnatal Depression Scale. British Joumal of Psychiatry 1987; 150: 782-786.

Danasabe M, \& Elias NB.(2016). Relationship between postpartum depression and problem solving ability among postpartum women in Nigeria. IOSR journal of humanitis and social science, 21(4), 81-89.

D'zurilla TJ, \& coldfried MR.(1971). Problem solving and behavior modification. Joumal of Abnormal psychology,78, 101-126.

$$
\begin{aligned}
& \text { عصبى منحصربهفردى هستند. از آنجا كه سيستمهاى } \\
& \text { عصبى تحت تأثير اضطراب و افسردگى بعد از زايمان با } \\
& \text { يكديخر همبوشانى دارند و با سيستمهاى درگير در } \\
& \text { رفتارهاى مراقبتى مادرانه، تعاملات مادر و نوزاد، تعامل } \\
& \text { مى كنند، اين سيستمها به شدت در معرض اختلال قرار } \\
& \text { مى گيرند؛ بنابراين، در ميان سلامت روان مادران، رابطه } \\
& \text { مادر-نوزاد و مكانيسمهاى نوروبيولوزيكى، اثر متقابل } \\
& \text { ييجيدهاى وجود دارد؛ اما با اين حال بيان جنين نتايجى } \\
& \text { مستلزم يُوهش هاى آتى بيشترى در اين زمينه است جرا } \\
& \text { كه ئزوهش حاضر نيز مانند اغلب مطالعات، با برخى } \\
& \text { محدوديتها از جمله حجم كو جكك نمونه آمارى مادران } \\
& \text { پس از زايمان، روش نمونه گيرى در دسترس، گروه سنى }
\end{aligned}
$$

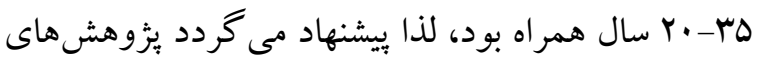

$$
\begin{aligned}
& \text { آتى در بازههاى سنى متفاوتى كاركردهاى شناختى } \\
& \text { مادران را مورد بررسى قرار دهند. } \\
& \text { سياسگزارى } \\
& \text { اين مطالعه يزوهشى حاصل باياننامه كارشناسى ارشد } \\
& \text { روانشناسى شناختى، دانشكده علوم تربيتى و روانشناسى } \\
& \text { دانشگاه شهيد مدنى آذربايجان، بر اساس كد اخلاقى } \\
& \text { IR.TBZMED.REC.1396.941 است. بيزوهشخران } \\
& \text { اين مقاله يُزوهشى بر خود وظيفه مىدانند تا از تمامى } \\
& \text { همكاران مراكز سلامت سطح شهر تبريز كه در اين } \\
& \text { يثوهش ما را يارى رساندند و به خصوص همه مادرانى } \\
& \text { كه با وجود شرايط سخت دوران بِ از زايمان ما را در } \\
& \text { به ثمر رساندن اين بثزوهش يارى نمودند، كمال تقدير و } \\
& \text { تشكر را داشته باشيم. }
\end{aligned}
$$

\section{References}


Gasemi N, \& Ahadi H. (1382). Study of the process of problem solving and metacognitive strategies development in children aged 3 to 11 years, Knowledge and research in applied psychology, 5(15), 39-60.[In Persian]

Ghanei Gheshlagh R, Mahmoodi H, \& Baghi V. (2015). A Comparison of Postpartum Depression between Fathers and Mothers in Saqqez. Psychiatric Nursing, 3(2), 72-79.[In Persian]

Howard LM, Molyneaux E, Dennis CL, Rochat T, Stein A, \& Milgrom J. (2014). Non-psychotic mental disorders in the perinatal period. Lancet, $\quad 384(9956), \quad$ 1775-1788. http//dx.doi.org/10.1016/S01406736(14)61276-9.

Khodadadi M, Nazarboland N, \& Amani H. (2014). N-back software, hnstitute for behavioral \& cognitive sciences, Tehran, Islamic Republic of Iran. [In Persian]

Lezak K. (1995). Neuropsychological Assessment. Oxford: University Press.

Messinis L, Vlahou Ch, Tsapanos V, Tsapanos A, Spilioti D, \& Papathanasopoulos P.(2010). Neuropsychological functioning in postpartum depressed versus nondepressed females and nonpostpartum controls. Joumal of clinical and experimental neuropsychology, 32(6), 661-666.
Mosallanejad L, \& Sobhanian S. (2010). The Accuracy of Edinburgh Postpartum Depression Test. Joumal of Jahrom University of Medical Seiences, 7(3), 1-6. DOI: 10.29252/jmi.7.4.1. [InPersian]

Namazi sh. (1378). The role of a number of psychological and demographic variables in postpartum depression, Hormozgan Medical Joumal, 3(1), 17-24. [InPersian]

Nejati V, \& Maleki G. (2012). The relationship between impulsive and reflective problem solving behavior. Zahedan J Res Med Sci (ZJRMS); 14(1): 76-81. [In Persian]

Parsons TD, Thompson E, Buckwalter DK, Bluestein BW, Stanczyk FZ, \& Buckwalter JG.(2009). Pregnancy history and cognition during and after pregnancy. Intemational Journal of Neuroscience. Volume 114(9), 1099-1110.

Sulso, \& Robert L. (1979). Cognitive Psychology. Translator: Maher, F. (1371), First Edition, Tehran, Grow Publishing.

Vestberg T, Reinebo G, Maurex L, Ingvar M, \& Petrovic P. (2017). Core executive functions are associated with success in young elite soccer players. PLOS ONE, 12(2): doi:10.1371/joumal.

Visani Y, \& Sayeh Miri K.(2012). Prevalence of Postpartum Depression in Iran - by systematic review and meta-analysis. IJOGI, Vol. 15, No.14, 21-29. 